\title{
DEEP VEIN THROMBOSIS IN SPINAL CORD INJURY: EFFECT OF PROPHYLAXIS WITH CALF COMPRESSION, ASPIRIN, AND DIPYRIDAMOLE
}

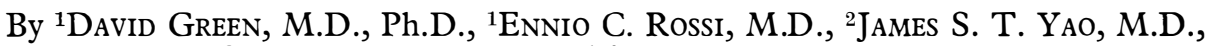 \\ ${ }^{3}$ W. R. FlinN, M.D., and ${ }^{4}$ Stewart M. Spies, M.D. \\ ${ }^{1}$ Professors of Medicine; ${ }^{2}$ Professor of Surgery; ${ }^{3}$ Assistant Professor of Surgery; ${ }^{4}$ Associate \\ Professor of Radiology: Northwestern University Medical School from the Atherosclerosis \\ Program, Rehabilitation Institute of Chicago, the Haematology Section, Department of \\ Medicine, and the Departments of Surgery and Radiology, Northwestern Memorial Hospital \\ $\mathcal{G}$ Northwestern University Medical School
}

Abstract. Deep Vein thrombosis is very common in spinal cord injury patients, and a randomized study comparing the prophylactic use of external pneumatic calf compression, aspirin and dipyridamole has been carried out.

Key words: Deep vein thrombosis; Spinal injury; Platelets; Factor VIII.

DEEP vein thrombosis (DVT) occurs frequently in patients with a history of recent trauma or surgery, especially when followed by prolonged immobilisation (Sevitt \& Gallagher, I96I; Sevitt, I969). Therefore, it would be anticipated that the incidence of DVT would be high in individuals with acute spinal cord injury (SCI). Recently, we reported the presence of DVT in I3 of I8 consecutive patients with complete lower limb paralysis (Rossi et al., I980). As compared to those without thrombosis, patients with DVT had more elevated levels of the von Willebrand factor (ristocetin-cofactor, VIII:RCof) and factor VIII related antigen (VIIIR:Ag), hyperactive platelet aggregation responses to collagen, and the appearance of circulating platelet aggregates coincident with the detection of thrombosis. We have now had the opportunity of examining the effect of prophylactic measures on the incidence of DVT and the above-mentioned haemostatic factors.

\section{Methods}

A prospective clinical trial of DVT prophylaxis was carried out in 28 consecutive patients with acute SCI and complete lower limb paralysis; all were male except four. Subjects were randomised to one of two regimens: external pneumatic calf compression (EPCC) alone in I5, and EPCC combined with aspirin (ASA), $300 \mathrm{mg}$ bid, and dipyridamole (Dip) $75 \mathrm{mg}$ tid in $\mathrm{I} 3$. EPCC was administered using a Jobst Athrombic Pump (Model 66-20, Toledo, Ohio) set for I min cycles with I $5 \mathrm{sec}$ calf compression at $40-45 \mathrm{mmHg}$.

DVT was detected by daily monitoring of the legs for the local uptake of

This study was supported in part by Research Grant No. I3-59I I I/5-03 (after 9/I/80, I3-59III/5-04) from the National Institute of Handicapped Research, Department of Education, Washington, D.C., 20202.

Address all correspondence to: Dr David Green, Atherosclerosis Program, Northwestern University, Rehabilitation Institute of Chicago, 345 East Superior Street, Room I407, Chicago, Illinois 606I I. 
${ }^{125}$ I-labelled fibrinogen (Abbott Scientific Products, N. Chicago, Illinois). The thyroid was blocked with SSKI, and fibrinogen injections were given at approximately IO-day intervals to maintain statistically meaningful count rates. Impedance plethysmography was performed on admission and every 72 hours thereafter. All positive tests were confirmed by contrast venography.

Haematological studies were obtained within 72 hours of spinal cord injury and repeated at 3-day intervals for a period of I month. Platelet aggregation studies were performed according to the method of Born (I962) using soluble collagen prepared as we have previously described (Green et al., 1973). The amount of collagen required to produce half-maximal aggregation velocity $(\mathrm{Kd})$ was measured as reported by us previously (Rossi \& Louis, 1977). Circulating platelet aggregates (platelet aggregate ratio) were assessed as described by Wu and Hoak (I974). VIII:C was assayed by Denson's modification (I966) of the method of Biggs et al. (I955), VIII:RCoF by the method of Weiss et al. (I973), and VIIIR:Ag by the Laurell technique (I972). Laboratory personnel were unaware of the prophylactic regimen the patients were receiving.

\section{Results}

\section{Incidence of DVT}

One of the 13 patients randomised to receive ASA/dipyridamole was transferred to another facility on day I4 of the trial, and therefore was not included in the data analysis; thrombosis had not been detected in this patient up to the time of transfer. Of the remaining 27 patients completing the study, DVT was detected in nine (33 per cent), an incidence significantly less than the 78 per cent we previously recorded in 37 patients not receiving prophylaxis $\left(\chi^{2}=\right.$ II $33, \mathrm{p}<$ $0.00 \mathrm{I})$. Although these untreated patients were not studied concurrently with those on prophylaxis, the criteria for case recruitment, the laboratory procedures, and the methods of management (aside from the prophylaxis), were identical. The thrombi in patients not receiving prophylaxis were generally diagnosed between days 4 and 12 after injury, whereas the peak incidence of DVT in the treated patients was between days 7 and 15 (Fig. I). Thrombi developed in six of 15 patients treated solely with EPCC, and in three of 12 receiving ASA/ dipyridamole as well as EPCC. This difference was not statistically significant $\left(\chi^{2}=0.17, \mathrm{p}<0 . \mathrm{I}\right)$. The six thrombi in the EPCC group were evenly divided between the popliteal and calf veins; of the three thrombi in the ASA/dip subjects, one was in the popliteal area and two were in the calf. None were in more proximal veins. In contrast, 23 per cent of the thrombi in our untreated patients were in the ilio-femoral veins. Prophylaxis was discontinued on day 30 after injury, but in three patients DVT developed on days 34 and 35. Two of these patients had been treated with EPCC and ASA/dipyridamole, and one had received EPCC alone.

\section{Haemostatic Studies}

\section{Platelet Aggregation}

The platelet aggregate ratios (PAR) of treated and previously untreated patients were initially within the normal range, but by day 6 had declined in the untreated group, and remained significantly reduced for the next Io days (Fig. 2). 


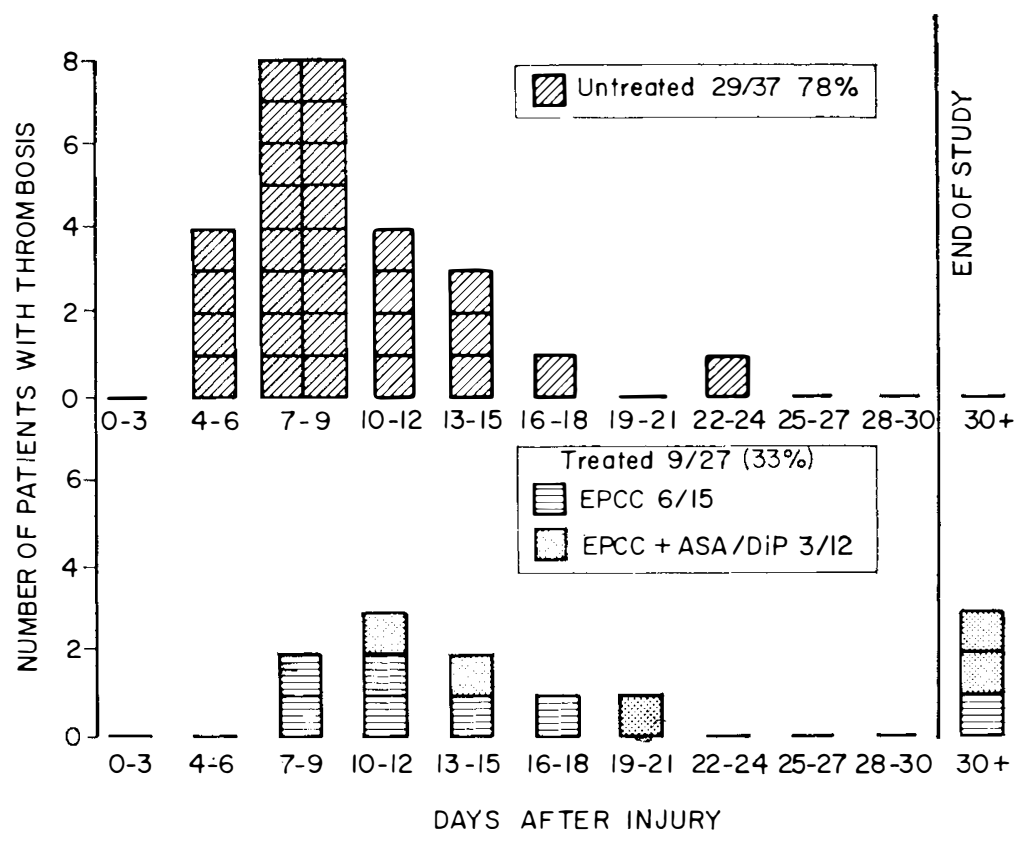

FIG. I

Deep vein thrombosis in untreated patients and in those receiving external pneumatic calf compression (EPCC), aspirin (ASA), and dipyridamole (Dip).

No differences were observed in the PAR of patients treated with EPCC alone or EPCC combined with aspirin and dipyridamole.

The amount of collagen required to produce half-maximal aggregation velocity $(\mathrm{Kd})$ was also reduced in untreated patients beginning on day 4 (Fig. 2), and this increased platelet responsiveness to collagen persisted throughout the entire study. In treated patients (excluding those receiving aspirin and dipyridamole), the $\mathrm{Kd}$ was generally within the low normal range, but was not significantly different from the untreated group except on days 4-6 and 28-30.

\section{Factor VIII Activities}

Factor VIII coagulant activity (VIII:C), ristocetin cofactor activity (VIII:RCoF), and VIII-related antigen (VIIIR:Ag) in the untreated patients were all significantly increased above the values for treated patients (and normal subjects) from the seventh through the twelfth day after injury. An examination of the factor VIII levels of patients treated with EPCC alone as compared to those also receiving aspirin and dipyridamole revealed that the latter in general had lower levels, although these reached statistical significance only for factor VIIIrelated antigen during days I3-I5 (Fig. 3).

\section{Side Effects}

One subject who required cervical spine fusion while receiving aspirin and dipyridamole bled extensively during surgery and required $1500 \mathrm{ml}$ of blood replacement. No untoward effects were observed in the remainder of the patients. 


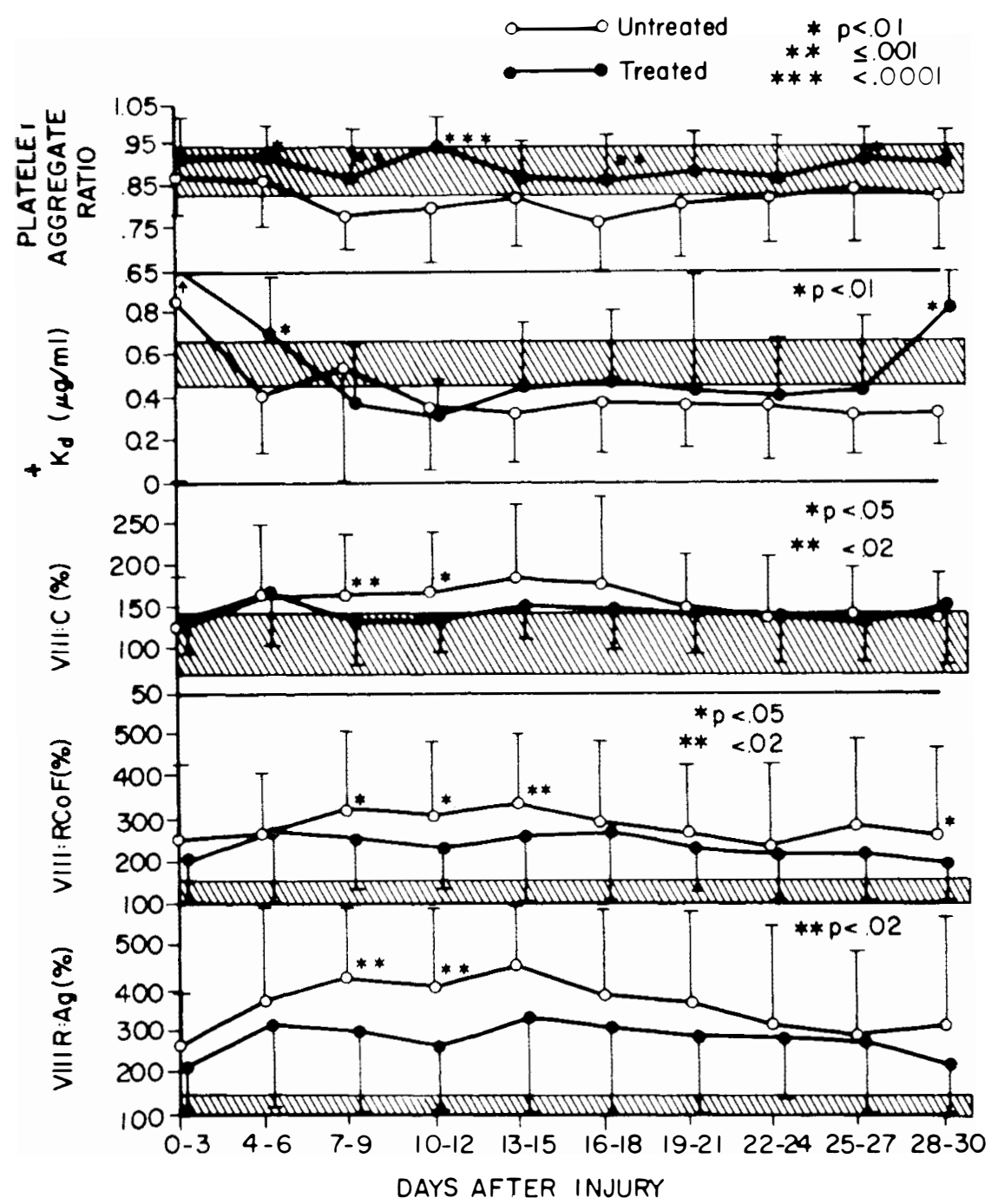

+ Excluding ASA

FIG. 2

Mean \pm one S.D. for platelet aggregate ratio, platelet collagen affinity $(\mathrm{Kd})$, factor VIII coagulant activity (VIII:C), factor VIII-ristocetin cofactor (VIII:RCoF), and factor VIII related antigen (VIIIR:Ag) in 62 patients with spinal cord injury. Treated patients received external pneumatic calf compression alone or combined with aspirin and dipyridamole. The cross-hatched area represents the range of values in I9 normal subjects. $P$ values compare treated and untreated patients.

\section{Discussion}

Our previous studies (Rossi et al., I980) indicated that patients with acute spinal cord injury had an extraordinarily high incidence of DVT. Therefore, prophylactic measures to reduce the risk of DVT in this high risk patient population were considered justified. External pneumatic calf compression has previously 


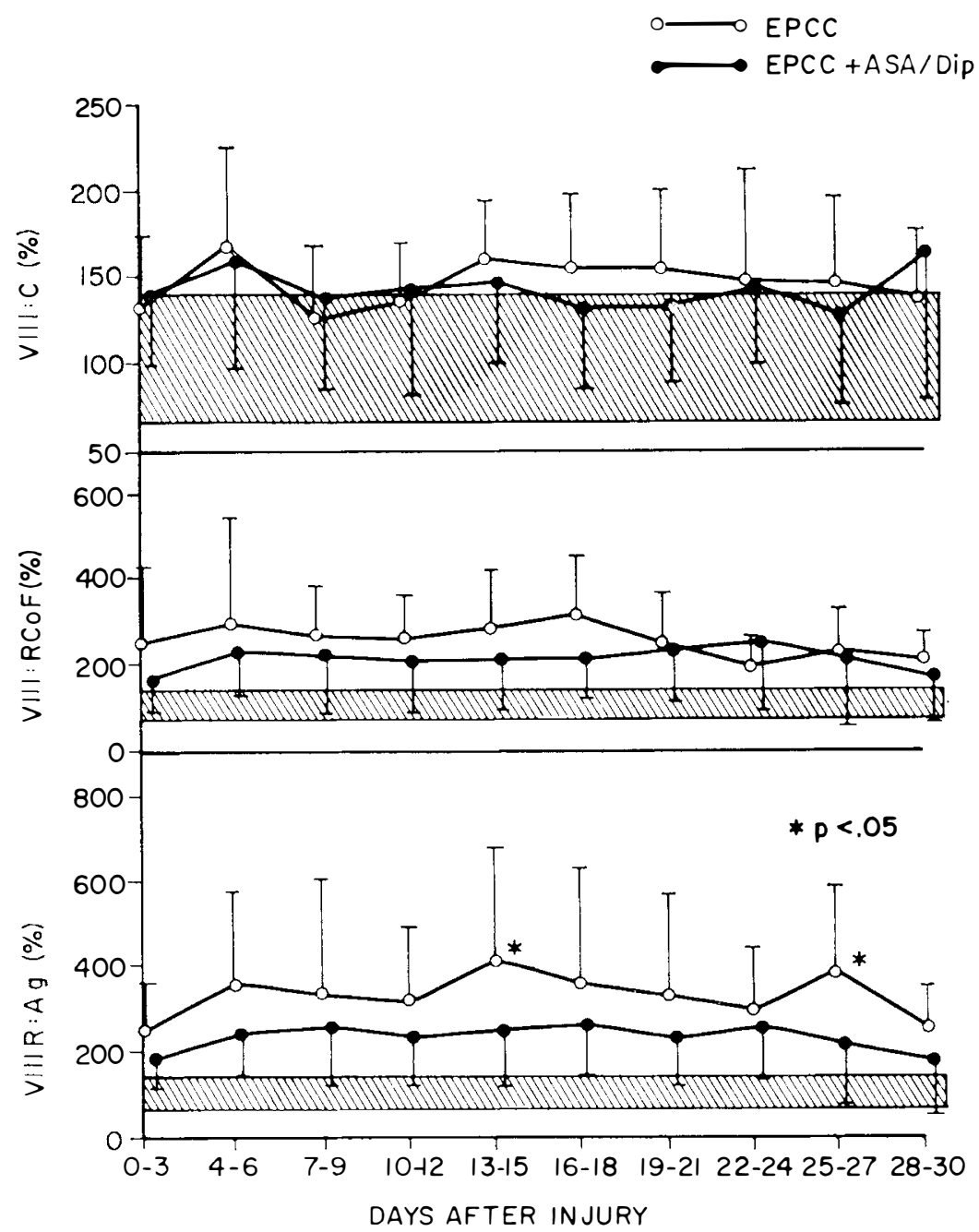

FIG. 3

Mean \pm one S.D. for factor VIII coagulant activity (VIII:C), factor VIII-ristocetin cofactor (VIII:RCoF), and factor VIII-related antigen (VIIIR:Ag) in I4 patients treated with external pneumatic calf compression (EPCC) vs. I I patients treated with EPCC, aspirin (ASA), and dipyridamole (Dip). The cross-hatched area represents the range of values in I9 normal subjects. P values compare EPCC alone to EPCC + ASA/Dip.

been shown to be safe and effective in decreasing the incidence of DVT in patients undergoing surgical procedures (Hills et al., I972; McKenna et al., 1980), and it was therefore applied to all our patients. The rationale for the addition of aspirin and dipyridamole to EPCC was based on several factors. Firstly, Walsh et al. (1976) showed that coagulant activities attributable to platelets play an important role in the pathogenesis of DVT in patients undergoing hip surgery. Platelet coagulant and anti-heparin activities increased progressively and significantly in patients developing DVT, whereas no changes were observed in those without DVT. Our own studies in the SCI patients confirm these observations. Platelet 
affinity for collagen progressively increased in untreated patients, 78 per cent of whom subsequently developed DVT. Secondly, Salzman et al. (I97I) reported that the incidence of DVT in patients undergoing hip arthroplasty was reduced from 34 per cent to 9 per cent $(p<0.02)$ by aspirin prophylaxis, and similar results were reported in a study of subjects undergoing total knee replacement (McKenna et al., I980). Thus, it appeared that the addition of aspirin might further enhance the effectiveness of EPCC. However, both of the aforementioned studies suggested that relatively large doses of aspirin would be required $(0.6 \mathrm{G}$ twice daily and $\mathrm{I} \cdot 3 \mathrm{G}$ thrice daily, respectively). We were reluctant to give doses of this magnitude to our patients with SCI in view of the high incidence of haemorrhagic gastritis in these patients; therefore, we combined small doses of aspirin with dipyridamole since it has been hypothesised that the two agents may act synergistically to inhibit platelet function (Moncada \& Vane, I979).

The results of our study indicate that EPCC alone reduces the incidence of DVT from 78 per cent to 40 per cent, and that the addition of ASA/dipyridamole results in a further reduction to 25 per cent. Furthermore, the onset of DVT is delayed by these prophylactic measures and thrombi were not detected in the ilio-femoral veins. However, while EPCC was well-tolerated by our patients, one subject receiving ASA/dipyridamole experienced significant bleeding during surgery, suggesting that these drugs should be used with caution if invasive procedures are contemplated.

Haemostatic studies showed that the increased platelet-collagen affinity, circulating platelet aggregates, and elevated factor VIII activities which are observed in untreated patients, are partially prevented by the use of EPCC alone. Calf compression may disperse the unusually high local concentrations of factors II, V, and VIII in limbs where venous stasis is present (Houghton et al., I978) preventing the local generation of thrombin and thrombin-induced platelet activation. The addition of ASA/dipyridamole to EPCC further normalises the haemostatic factors with a corresponding reduction in DVT. Thus, these prophylactic measures provide an effective deterrent against thrombosis in the spinal cord-injured patient.

\section{SUMMARY}

Twenty-eight consecutive patients with acute spinal cord injury were randomised to one of two regimens for the prevention of deep vein thrombosis (DVT): external pneumatic calf compression (EPCC, I 5), or EPCC combined with aspirin, $300 \mathrm{mg}$ bid, and dipyridamole, $75 \mathrm{mg}$ tid (ASA/dip, I3). DVT, detected by the ${ }^{125}$ I-fibrinogen test and impedence plethysmography, was confirmed by contrast venography. The incidence of DVT in the total group was 33 per cent, significantly less than the 78 per cent observed in 37 untreated patients studied previously $(p<0.001)$. DVT developed in six of I 5 patients receiving only EPCC, and three of 12 on ASA/dip as well as EPCC $(p<0 \cdot I)$.

The untreated patients studied earlier had significantly increased circulating platelet aggregates, increased platelet affinity for collagen, and elevated factor VIII activities, which generally coincided with the development of DVT (usually 7-9 days after injury). Prophylaxis partially prevented these coagulation abnormalities and delayed the onset of thrombosis. While the differences in the haemostatic parameters between those not treated with ASA/dip and those receiving these agents were not statistically significant (except for the platelet-collagen affinity), there was a trend toward less elevated values in the drug-treated patients. We 
conclude that spinal cord injury patients are at extreme risk for DVT, and have abnormal platelet and factor VIII activities. Prophylaxis with EPCC significantly and safely reduces the risk of DVT in these patients.

Acknowledgement. We thank K. Hansen, H. Kohl, G. Louis, L. Peterson and $\mathrm{N}$. Reynolds for their expert technical assistance and E. Lee for the preparation of the manuscript.

\section{RÉSUMÉ}

Vingt huit malades admis de façon consecutive à la suite d'une lésion aiguë de la colonne vertébrale ont été soumis au hasard à l'un des deux régimes suivants pour prévenir la thrombo-phlébite: compression pneumatique externe du mollet (CPEM, I5 cas) et CPEM associé au traitement à l'aspirine, $380 \mathrm{mg} 2$ fois par jour, et au dipyridamole, $75 \mathrm{mg}$ 3 fois par jour (ASP/DIP). La thrombo-phlébite, détectée par les tests du fibrinogène iodiné radioactif et de 'impedence plethysmography', a été confirmée par la veinography de contraste. L'incidence de thrombo-phlébite dans le groupe entier est de $33 \%$, bien moindre que celle de $78 \%$ observée dans 37 cas non-traités étudiés auparavant $(\mathrm{P}<0,00 \mathrm{I})$. La thrombo-phlébite s'est développée dans 6 cas sur I 5 recevant la CPEM et dans 3 cas sur I 2 recevant le traitement combiné CPEM/ASP/DIP.

Les malades non-traités étudiés auparavant ont une augmentation significative d'aggrégats plaquettaires circulants, une affinité accrue des plaquettes pour le collagène et une augmentation des activités du facteur VIII qui coincident en général avec le dévelopment de la thrombo-phlébite (en général 7-9 jours après la lésion). Le traitement prophylactique prévient partiellement les anomalies de coagulation et retarde l'initiation de la thrombose. Bien que les paramètres d'hémostase des malades traités à l'ASP/DIP et de ceux non-traités ne soient pas bien différents (exception faite pour l'affinité plaquettescollagène), une tendance à des taux moins élevés est notée chez les malades sous-traitement. En conclusion, les malades présentant une lésion aiguë de la colonne vertébrale risquent fort la thrombo-phlébite et ont une fonction plaquettaire anormale aussi bien que des taux élevés du facteur VIII. Le traitement prophylactique de CPEM réduit de façon significative et sans danger le risque de thrombo-phlébite chez ces malades.

\section{ZUSAMMENFASSUNG}

Achtundzwanzig aufeinanderfolgende Patienten mit akuter Rückenmarkverletzung wurden aufs Geratewohl in zwei Disziplinen eingeteilt zur Verhinderung von Thrombose in tief gelegenen Venen: externe pneumatische Wadenkompression, oder externe pneumatische Wadenkompression mit Aspirin, $300 \mathrm{mg}$ bid, und Dipyridamole, $75 \mathrm{mg}$ tid (ASA/dip, I3). Thrombose in tief gelegenen Venen, festgestellt mit dem ${ }^{125}$ I-Fibrinogen Test und Plethysmographie wurde durch Kontrastvenographie bestätigt. 33\% aller Fälle entwickelten Venenthrombosen, bedeutend weniger als $78 \%$ von 37 nicht behandelten Patienten, die vorher getestet wurden $(\mathrm{P}<0 \cdot 00 \mathrm{I})$. Tief gelegene Venenthrombose entstand in 6 von I5 Patienten, die nur externe pneumatische Wadenkompression erhielten und in 3 von I2, die mit Aspirin/dip und Wadenkompressen behandelt wurden $(\mathrm{P}<0 \cdot \mathrm{I})$.

Unbehandelte Patienten, die vorher getestet wurden, hatten zirkulierende Thrombozyten Aggregate, erhöhte Thrombozyten-Kollagen Affinität und erhöhte Faktor VIII Aktivität, was im algemeinen im Zusammenhang stand mit der Entstehung von Thrombosen (gewönlich 7-9 Tage nach der Verletzung). Prophylaxe verhinderte teilweise diese Gerinnungsabnormalitäten und verschob den Beginn der Thrombose. Während die Unterschiede in den hämostatischen Parametern zwischen der mit ASA/dip behandelten Gruppe und den Patienten die keine Medikamenten erhielten nicht statistisch von Bedeutung sind (außer der Thrombozyten-Kollagen Affinität) zeigte sich eine Tendenz zu niedrigeren Werten in den mit Medikamenten behandelten Patienten. Wir beschließen, daß rückenmarkgelähmte Patienten in äußerster Gefahr sind Thrombosen zu entwickeln und abnormale Thrombozyten und Faktor VIII Aktivitat haben. Prophylaxe mit externer pneumatischer Wadenkompression reduziert bedeutend und sicher die Gefahr von Venenthrombosen in diesen Patienten. 


\section{REFERENCES}

Biggs, R., Eveling, J. \& Richards, G. (I955). The assay of antihaemophilic-globulin activity. Br. F. Haemat., I, 20-34.

BorN, G. V. R. (I962). Aggregation of blood platelets by adenosine diphosphate and its reversal. Nature, 194, 927-929.

Denson, K. W. E. (I 966). Reagents and Techniques. Treatment of Haemophilia and Other Coagulation Disorders (ed. by R. Biggs and R. G. MacFarlane), p. 337, Blackwell Scientific Publications, Oxford.

Green, D., Dunne, B., Schmid, E. R., Rossi, E. C. \& Louis, G. (I973). A study of the variable responses of human platelets to collagen: relation to aspirin-induced inhibition of aggregation. Am. F. Clin. Path., 60, 920-926.

Hills, N. H., Pflug, J. J., Jeyasingh, K., Boardman, L. \& Calnan, J. S. (I972). Prevention of deep vein thrombosis by intermittent pneumatic compression of calf. $\mathrm{Br}$. Med.F., i, I3I-I 35 .

Houghton, G. R., Papadakis, E. G. \& Rizza, C. R. (1978). Changes in blood coagulation during total hip replacement. Lancet, i, I336-1338.

Laurell, C. B. (I972). Electroimmunoassay. Scand. F. Lab. Invest., 29 (Suppl. 124), $2 \mathrm{I}-38$.

McKenna, R., Galonte, J., Bachmann, F., Wallace, D. L., Kaushal, S. P. \& Meredith, P. (I980). Prevention of venous thromboembolism after total knee replacement by high-dose aspirin or intermittent calf and thigh compression. Br. Med.f., i, 5I4-5I 7 .

MoncADA, S. \& VANE, J. R. (1979). Arachidonic acid metabolites and the interactions between platelets and blood vessel walls. N. Engl. F. Med., 300, I I42-I I 47.

Rossi, E. C., Green, D., Rosen, J. S., Spies, S. M. \& YAO, J. S. T. (I980). Sequential changes in factor VIII and platelets preceding deep vein thrombosis in patients with spinal cord injury. Br.F. Haemat., 45, I43-I 5I.

Rossi, E. C. \& LouIs, G. (I 977). Kinetic parameters of platelet aggregation as an expression of platelet responsiveness. Thromb. Haemost., 37, 283-290.

Salzman, E. W., Harris, W. H. \& De Sanctis, R. W. (I97I). Reduction in venous thromboembolism by agents affecting platelet function. N. Engl. F. Med., 284, I $287-$ I 292 .

SevitT, S. (I969). Venous thrombosis in injured patients with some observations on pathogenesis. Thrombosis (ed. by S. Sherry, K. M. Brinkhous, E. Genton \& J. M. Stengle), Nat'l. Acad. Sci., pp. 29-49, Washington.

Sevitt, S. \& Gallagher, N. (I96I). Venous thrombosis and pulmonary embolism. A clinicopathological study in injured and burned patients. Br. F. Surg., 48, 475.

Walsh, P. N., Rogers, P. H., Marder, V. J., Cagnatelli, G., Escovitz, E. S. \& Sherry, S. (I976). The relationship of platelet coagulant activities to venous thrombosis following hip surgery. Br.F. Haemat., 32, 42 I-437.

Weiss, H. J., Hoyer, L. W., Rickles, F. R., Varma, A. \& Rogers, J. (I973). Quantitative assay of a plasma factor deficient in von Willebrand's disease that is necessary for platelet aggregation. F. Clin. Invest., 52, 2708-2716.

Wu, K. K. \& HoAK, J. C. (I974). A new method for the quantitative detection of platelet aggregates in patients with arterial insufficiency. Lancet, ii, 924-926. 